\title{
Our Contributors / Nos collaborateurs
}

ELIZABeth HUlSe is a librarian at the Thomas Fisher Rare Book Library, University of Toronto, and editor of the Papers of the Bibliographical Society of Canada.

DAVID B. KOTIN is Head of the Canadiana Collection at the North York Public Library; he is the editor of Reader, Lover of Books, Lover of Heaven (Willowdale: North York Public Library, 1978).

RICHARD G. LANDON is Head of the Thomas Fisher Rare Book Library, University of Toronto; he teaches courses in Descriptive Bibliography and Rare Books in the Faculty of Library Science, University of Toronto.

WILlIAM F.E. MORLEY is Curator of Special Collections at the Douglas Library, Queen's University; he is the founder and editor of Canadian Notes 屯) Queries and author of A Bibliographical Study of Major John Richardson, published by the Society in 1973 .

ROY STOKES is Director of the School of Librarianship at the University of British Columbia; he is the author of The Function of Bibliography (London: A. Deutsch, 1969) and Michael Sadleir 1888-1957 (Metuchen, N.J., \& London: Scarecrow Press, 1980).

JOHN A. WISEMAN is Associate Librarian of the Thomas J. Bata Library, Trent University. He has recently completed a study of reading materials and the reading public in nineteenth-century Ontario (entitled 'To Amuse and Instruct'), which he hopes to publish in the near future.

PAUL WYCZYNSKI'est titulaire de recherche à l'Université d'Ottawa et codirecteur du projet Garneau au Centre de recherche en civilisation canadiennefrançaise. 